In the face of the pandemic $\mid 146$

FRANCISCO HIDALGO ${ }^{1}$

\title{
In the face of the pandemic: The potential of rurality and peasant agriculture $\mathrm{e}^{2}$
}

At the beginning of July 2020, in Ecuador, as in most of the countries of the region, started loosening emergency lockdown restrictions designed to tackle COVID-19 pandemic. In Ecuador, the governmental discourse drew upon the illustrative figure of colours in the traffic lights: high-risk zones depicted as red; the colour yellow to denote control over the pandemic and green delineating lower risk zones.

At the time of writing, most of the country was considered "yellow", meaning that the pandemic is under control. As of July 4 2020, the official government records registered 61,135 positive cases and 4,719 fatalities from a total 162,000 COVID tests. Most of the cases of infection and deaths caused by COVID-19 occurred in urban centres such as Guayaquil, Quito, Manta-Portoviejo, which accounted for $60 \%$ of the registered cases. The newspaper El Comercio showed the relationship between the average age and infected people was as follows: $58 \%$ of the cases were people between 20 and 49 years of age, $22 \%$ in the population between 50

to 64 years, with a higher incidence in men, 55\%, while women accounted for 45\% (El Comercio 04/07/2020).

\footnotetext{
${ }^{1}$ Francisco Hidalgo is Professor of Agrarian Sociology and Sociology of Development at the Faculty of Social and Human Sciences of the Central University of Ecuador. he is also a Researcher of the Research System on the Agrarian Problems of Ecuador - Sipae.

${ }^{2}$ This article was originally published in http://www.alternautas.net/blog/2021/9/8/in-the-face-ofthe-pandemic-the-potential-of-rurality-and-peasant-agriculture
} 


\section{Ending Restrictions}

Initially, Ecuador was one of the countries with the highest incidence of COVID19 in Latin America but with the progressive expansion of the pandemic in the region, other countries such as Brazil, Peru and Chile overtook Ecuador in terms of incidences of COVID per 100,000 people, whilst United States became the country where the virus spread the most.

The end of the lockdown period had numerous risks already pointed out by some analysts. Risks related to tensions on the productive and economic structures were much higher than those related to adequate health conditions. Health experts also pointed out the risks of "a second wave of contagion" which could severely affect poor and marginalised sectors in the big cities, which could in turn spread the disease to rural areas, where the number of cases was relatively low.

In the Ecuadorian case, an additional factor that worsened the situation was the opportunistic imposition of neoliberal economic and political measures by the government in the name of responding to the crisis. The government's previous attempt to implement these neoliberal policies pre-pandemic sparked an indigenous-popular uprising in October 2019 that forced the government to back down.

In order to tackle the health crisis and its attendant economic effects, the government introduced measures such the expansion of labour flexibility, the dismissal of employees from both public and private companies the downsizing of the state through privatisation. As result, the so called "new normal" was nothing less than the return to normalcy, albeit with stronger impacts on the working classes. In order to analyse the impacts of this "new normal", this article examines the challenges of food issues at the moment when Ecuador ended lockdown restrictions.

\section{The Contribution of Food Producers}

Between March and June 2020, the health crisis and the state of emergency followed by the total closure of national borders put food production at the centre of national public attention, since national food production is mainly supplied by peasant and family farming. 
In the face of the pandemic $\mid 148$

Then, as seldom before, the crucial link between the reproduction of life and agriculture became apparent for all to see. In this moment, agriculture could not be reduced to a simple economic reading and framed as "production for the national market". The importance of food production goes beyond recognising that it "serves the national market"; it is a central pillar of the reproduction of life that affects all the population, even majoritarian social groups. It is not only about "satisfying domestic demand" - an abstract the quantitative measure - although its persistence and potential questions the predominant organisation of agricultural production.

The time has come for the elites, who elaborate and implement public policies, to recognise the paramount role that peasant and family agriculture plays in capitalism today. During the state of emergency and border closures, the Ecuadorian experience showed the capacity of this sector to supply food to the majority of the national population, revealing an alternative to the globalised, industrialised model of food production that came to prominence during the latter decades of the twentieth century.

Moreover, statements from official spokespersons ${ }^{3}$ point out that there were signs that the demand of products such as rice, citrus fruits, vegetables, bananas, dairy products and eggs improved when supplied by peasant and family agrarian production, which also increased self-sufficiency of communities in rural areas. It should also be noted that there were urban-marginal sectors that suffered from food shortages. However, these were linked to the structural conditions of poor distribution and state failure in food distribution for poor neighbourhoods rather than production per se.

The significance of peasant and family farming, including indigenous and Afrodescendant communities in the national food production can be seen in the following graph (Graph No. 1). ${ }^{4}$ The graph shows the size of the productive units dedicated to transitory crops that are key for the national consumption: rice, hard maize, soft maize, potatoes, vegetables, cereals, among others. Moreover, the graph clearly shows that most of the products from the transitory crops are

\footnotetext{
${ }^{3}$ Available at El Comercio, https://www.elcomercio.com/actualidad/emergencia- incidio-preciosproductos-ecuador.html

${ }^{4}$ Graphic 1. Source: Espac 2017. Graphic processing: María Jose Quishpe y Eliana Anangonó Sipae.
} 
cultivated in peasant's productive units (those smaller than 5 hectares), that correspond to 431,048 Productive units and cover a total of 326,077 hectares. Along the same line, the Productive family units (those between 5 and 20 hectares) build an important segment in the agrarian production and correspond to 124,212 production units covering a total of 368,698 hectares.

There are also large landholdings in the production of transitional crops, especially on the Coastal region (Pacific) mainly rice and hard maize. However, big capital is not found in these sectors, but is concentrated in agro-exportation products such as bananas, flowers and shrimp. Ecuadorian peasant and familiar agriculture make a determinant contribution to supply food for both population in the countryside and urban areas, particularly those with low-income sectors.

Chart N. 1 Size of productive units and transitional crops

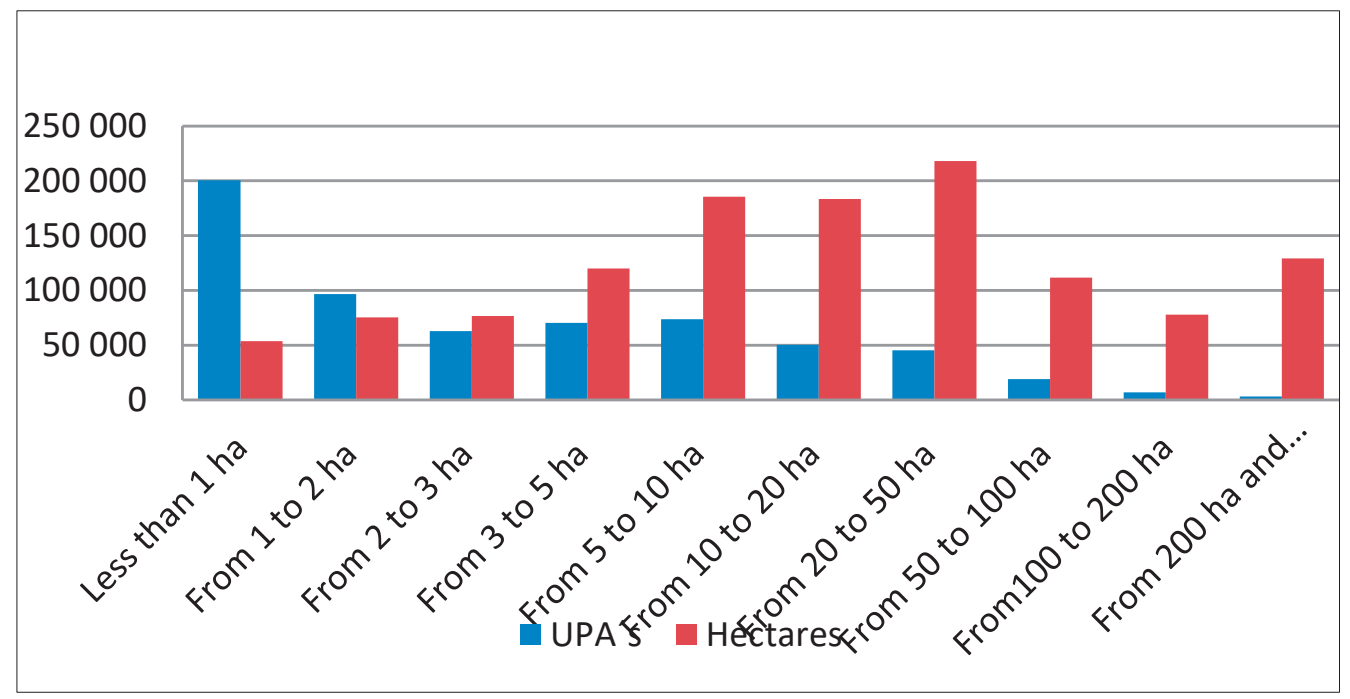

\section{Recovering the Food Sovereignty Horizon}

It is necessary to ask whether the advent of a "new normality" will place peasant and family agriculture once again on a marginal level, without visibility, or whether it will be considered in the design of national strategies and governmental plans to promote human wellbeing for the national population. 
In the face of the pandemic $\mid 150$

The health emergency and global confinement also challenged the neoliberal paradigm and the rationale of "comparative advantages" in agriculture, especially, when considering the agricultural production patterns that boost national economies. The "comparative advantages" for the tropical countries have become a leading argument of the neoliberal policies and the development discourses; nevertheless, the assumed advantages have led rather to subtle impositions resulting in an asymmetrical distribution of agricultural production at the global level, with particularly egregious effects in the Global South countries. Even if not clearly expressed from the beginning in neoliberal thought, comparative advantages was used to justify the shift towards large-scale agro-industrial production of bananas, palm oil, shrimp, flowers among other things for export, side-lining the food security and nutritional needs of the domestic population.

The COVID-19 pandemic illuminates how this pre-eminence of agro-export makes national development fragile, leading to an underutilized agricultural and aquaculture sector capable of the feeding of the national population, affecting the reproduction of life in the country and the city. Both the state and social organisations need to learn lessons from the COVID-19 pandemic and question in depth to what extent "comparative advantages" and "insertion" to world market provide the right or wrong answers to the challenges of the current situation.

The threatening circumstances that emerged from the health and environmental crisis arising from COVID-19 as well as inequality made clear that national agriculture should be reframed in order to response and cope accordingly to nutrition issues. The crisis scenarios have created the conditions for a change in the understanding and way of thinking on food and agriculture. New horizons are now opening that anchor food sovereignty as central to realising good livingSumac Kawsay.

\section{Food Assistance During the National Emergency}

I argue that peasant and family food production network was a decisive factor mitigating further impacts that the pandemic could have produced during lockdown and the state of emergency. I suggest that a second crucial factor was food assistance programmes led by both the government and private 
conglomerates, although there were also several noteworthy initiatives formed outside the central spaces of power.

Regarding food assistance, both state monetary subsidies, as well as specific food provision programmes have helped confront the crisis. Private conglomerates initiatives have provided assistance both for health care, by building health centres, as well as for food supplies. Food assistance initiatives ranged from assistance from the national state, local and provincial governments and large private chains, and donations from banks and private companies, church and church-related entities to alternative initiatives from NGOs and farmers' organisations and urban and rural agro-ecological entrepreneurships.

The national government initially implemented two policies in order to address the food situation crisis. Firstly, it rolled out financial compensation in form of a coupon was given to families in conditions of poverty and extreme poverty. Secondly, the government enacted a food kits programme "Giving a hand without giving the hand", which was supported through agreements with the agroindustry, as well as the "Canasta Solidaria" (solidarity basket) and "Agrotienda Ecuador" (Agri-store Ecuador) ${ }^{5}$ programmes. Province and municipal governments have also contributed with food assistance by implementing sources that involved more directly family producers and local peasants. A well- known case was the "Quito Solidario" programme. The municipality of Quito has also created the programme "Ayuda a un abuelito" (Help a grandparent) and the prefecture of Azuay, the "Canasta Popular" programme.

Although the participation of large private conglomerates in some programmes helped to confront the critical situation, they have seized this opportunity to enhance their public image. The consortia was built within a network including different sectors such as banking, agribusiness and hypermarkets that operated in close relation, linking their common interests to achieve an impact at regional level. On the one hand, in Guayaquil, the former mayor Jaime Nebot acted through

5 Agrotienda Ecuador" articulates state and peasant producers. See: https://www.elcomercio.com/actualidad/entrega-canastas-agropecuarias-emergenciacovid19.html\#cxrecs_s 
In the face of the pandemic $\mid 152$

the "Private Emergency Committee" and, on the other, in Quito, through the "Fondo por Todos" which was supported by the former mayor Roque Sevilla. Additionally, some banking groups have been working together both by the front led by Banco Pichincha-Diners (Fidel Egas \& Cia.), as well as by the front led by Banco de Guayaquil (Guillermo Lasso \& Cia.).

It is not only the state and private organisations that have dealt with to the crisis, but mainly key initiatives from social organisations have played a significant role. The Peasant Brigades in Solidarity for Food Sovereignty in which the Federation of Peasant Organisations and the Conference on food sovereignty ${ }^{6}$ are two such key actors. The Exhibition Network of Pichincha, which brings together agroecological collective groups, as well as further initiatives of nongovernmental organisations such as "Urban-Rural bond in times of pandemic" have also provided important support. Additionally, alternative communication channels in social networks have highlighted the importance to call for peasant economy as a central topic of the debate in times of health crisis ${ }^{7}$.

\section{Fragility of Hyper-Urbanism and the Potential of Rural Areas during the Pandemic}

While the effects caused by the COVID-19 pandemic had shown great impacts in urban areas, especially in large cities, rural areas seem to have been comparatively less affected. The big cities, particularly, those which have experienced an accelerated growth in the last two decades have experienced intense fragility, itself a result of the concentration of power in the hands of private actors and the state, as well as the ideology of progress.

Quito is a good example of this acceleration process, becoming the most populated city in Ecuador in 2018, overtaking Guayaquil in the process. The urban expansion in both Quito and Guayaquil with more than three million inhabitants

\footnotetext{
${ }^{6}$ With the union of the countryside and the city we will get out of the crisis. See: https://rebelion.org/-

with-union-of-countryside-and-city-we-will-get-out-of-the-crisis/

${ }^{7}$ Regarding alternative initiatives from NGOs and the promotion of an alternative debate See Earth Monitoring: https://www.monitoreodelatierra.com/single-post/2020/06/ 17/Acciones-emprendidaspor-los-miembros-de-la-Estrategia-Nacional-de-Involucramiento -Ecuador- $\%$ E2\%80\%93-ENI-aprop\%C3\%B3sito-de-la-Pandemia-por-COVID-19-y-elsector-rural
} 
each one has led to marginality and lack of services instead of wellbeing for the migrant population. Big cities are currently the most evident example of inequality model that has been imposed on Ecuador: poor neighbourhoods with high population density, lacking health services, housing shortages, labour marginalisation, all those aspects that make these environments highly vulnerable to the pandemic turning urban population's life much more fragile.

This fragility should lead us to reconsider the importance of preserving rural life and to implement public policies in order to stop the emigration dynamics from the countryside to the cities, as well as to strengthen a long-term perspective of life preservation. The following chart shows the development in both urban and rural areas presented in the official report dated 4 July of July 4, 2020, issued by the National Government: "Situación Nacional por COVID-19 - report No. 128". It presents the situation in the province of Pichincha ${ }^{9}$, at the moment the second focus of spread of the coronavirus, with $17 \%$ of the total number of cases registered in Ecuador. The chart clearly shows the concentration of Covid-19 cases in Quito, over 8,000 registered, most of them in working-class neighbourhoods in the south, centre and north of the cities: Chillogallo, Guamaní, Belisario Quevedo, Cotocollao, Calderón. By contrast, in the rural areas of the province covid cases are lower or even very few, as in the Sierra Norte in the canton of Pedro Moncayo or in the north-western area in the canton of western area, the canton of San Miguel de los Bancos.

8 Available at https://www.elcomercio.com/actualidad/balance-muertes-contagioscovid19ecuador.htm

${ }^{9}$ For this and the following graphs the source is report 128, dated 04/07/2020 from the Ministry of Public Health. Ministry of Public Health. 
Chart N. 2 Covid-19 cases confirmed in the province of Pichincha

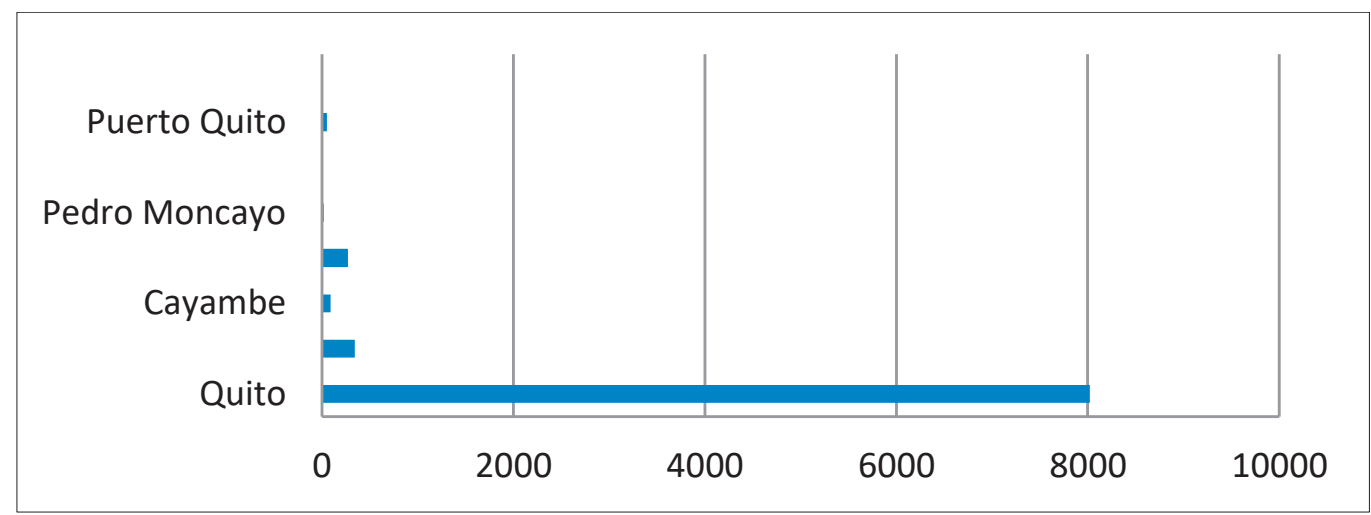

The following chart shows the Guayas province, where $29 \%$ of the of the cases registered at the national level were concentrated and which had a massive outbreak of coronavirus during April and May 2020. The chart clearly confirms the predominance of Guayaquil as a greatest agglomeration with a total of 11,200 registered cases. When considering the spread of epidemic cases in surrounding cities such as Durán, Daule, Samborondón, the poor urban environments are hotspots of the epidemic's spread. As in Quito, the spread of the disease became more acute in the working-class neighbourhoods which is also linked to the lack of health and sanitation services.

Chart N. 3 Covid-19 cases confirmed in the Province of Guayas

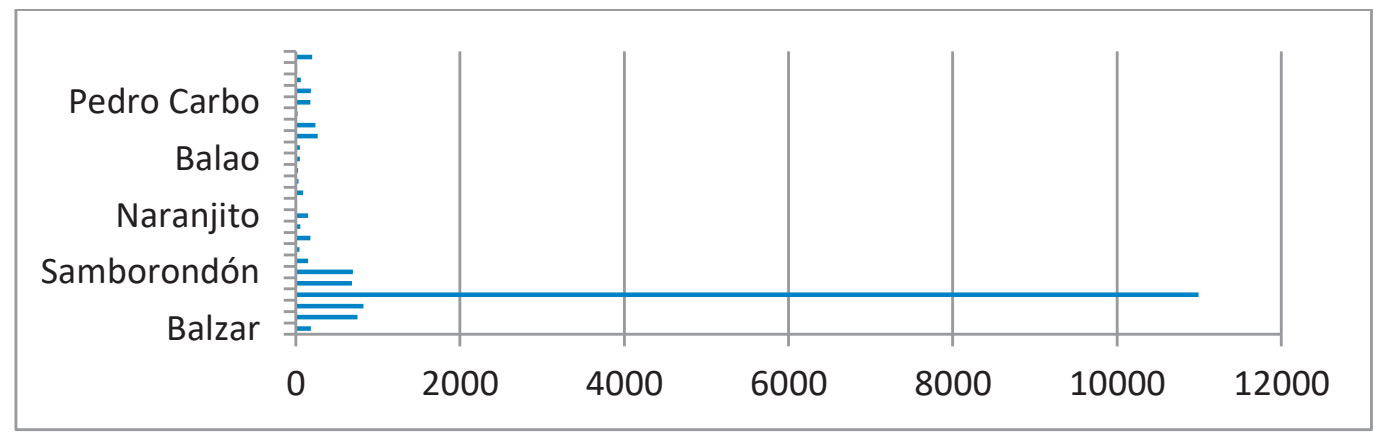


The registered COVID-19 cases in traditionally rural provinces such as Nobol, Santa Lucía, Palestina, Santa Lucía, Palestina, to mention just some, are lower than those in urban environments. The following chart shows the cases registered in the province of Bolívar (chart N. 5), located in the central highlands of Ecuador.

Chart N. 4. Covid-19 confirmed cases in the Province of Bolivar

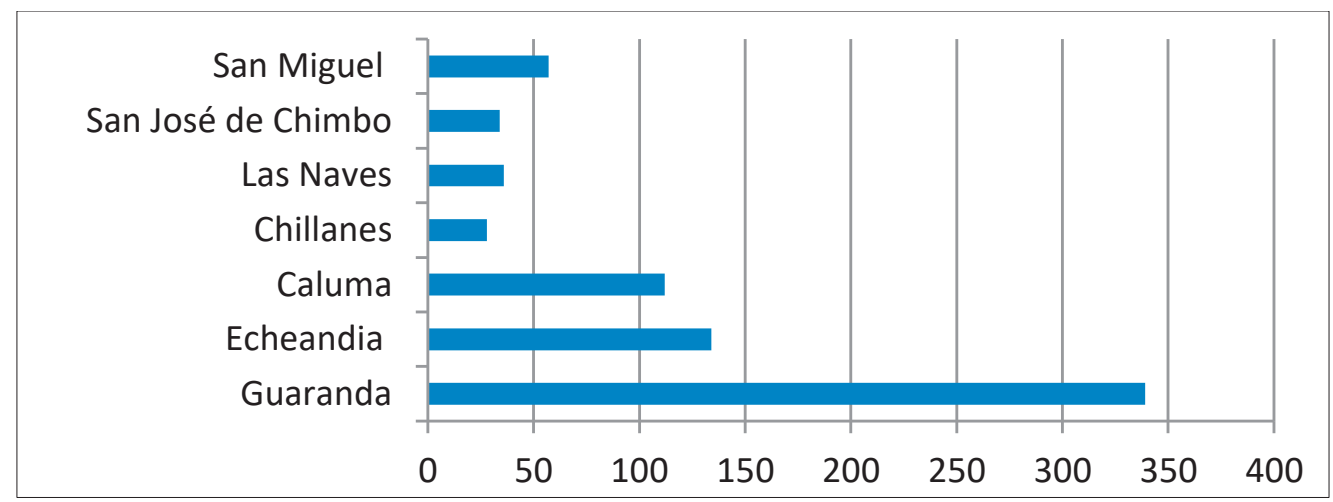

The chart above shows that, in the seven cantons that comprise the province Bolivar, 740 COVID-19 cases were registered, with approximately half of them concentrated in the provincial capital, the city of Guaranda with 340 cases, while the rural cantons had a relatively low COVID-19 registration rate, with four registering less than 50 cases per canton.

When comparing the registered cases, an entire rural province has registered solely 720 case, which is less than the cases of a single urban parish in a big city in the canton Guayaquil with 5,020 registered cases. Similarly, the infection record for the parish of Chillogallo in the metropolitan district of Quito reported $686^{10}$ while the development of three rural provinces average between 20 and 60 cases.

\footnotetext{
${ }^{10}$ La parroquia urbana de Guayaquil con mayores contagios, consultado en: diario El Universo https://www.eluniverso.com/noticias/2020/06/06/nota/7864245/coronavirus-parroquia-tarquiguayaquil-quito
} 
In the face of the pandemic $\mid 156$

The above data grouping the presented charts show that in geographical predominantly rural regions, the impact of the pandemic is considerably significantly less than in urban-dominated regions. I would argue that this points to the characteristic of rural areas - particularly the dispersion of the population and direct contact with nature - being increasingly crucial for the sustainability of life.

\section{Final remarks}

The spread of the COVID-19 pandemic - which as of mid-July 2020 had recorded 12,691,000 infections and 565,300 deaths worldwide and 3,326,000 infected and 143,350 deaths in Latin America - has driven academics, politicians, doctors, and humanity in general to evaluate and rethink the paths of global development which have been largely marked by global capitalist hegemony.

There is a consensus that the crisis exacerbated by the spread of the pandemic has its roots in important historical challenges that involved the whole humankind. Among the multiple considerations how to deal with the challenging circumstances of the pandemic, the Ecuadorian experiences show that peasant and family farming significantly contributes to mitigate the global warming, to consolidate rural territories and to preserve life. The evolution of the health crisis and confinement, in its various phases, in Ecuador is a good example of how peasant and family farming become a potential for rural regions. Consequently, it is necessary to re-evaluate key approaches such as food sovereignty and the development of productive diversity, equity and dispersal of power.

\section{Bibliography}

CEPAL (2020). "Sistemas alimentarios y COVID-19 en América Latina y el Caribe". https://repositorio.cepal.org/bitstream/handle/11362/45897/1/cb0501_es.pdf

FAO (2020). "La pandemia del coronavirus y los sistemas alimentarios en América Latina". $\quad$ http://www.fao.org/americas/publicaciones-audiovideo/covid19-y-sistemas-alimentarios/es/ 
Francisco Hidalgo Flor (2020). "Problemática alimentaria y crisis sanitaria". En: https://www.clacso.org/problematica-alimentaria-y-crisis-sanitaria-en-ecuador/

Jan Douwe van der Plog (2020). "De la crisis biomédica a la política médica: el sistema alimentario en tiempos del Covid - 19". https://www.tandfonline.com/

-Diario El Comercio del 5 de julio del 2020 información de prensa con el título "Ecuador reporta 61958 contagios de covid-19 y 7961 muertes en el contexto de la pandemia". 